\title{
National Research Council of Canada Industrial Materials Institute
}

Leszek A. Utracki*1

(訳)市 橋 秀 樹*2

The Industrial Materials Institute (IMI) は, National Research Council of Canada (NRCC) が持つ 20 の研究所, 技術センターの一つである。当研究所は, 材料の開発と加 工に関する研究開発活動を行うことにより，カナダの企業 を支援している。

主に研究対象となる材料は, 金属, セラミックス, ポリ マーであり, ポリマーは主にアロイ,ブレンド,コンポジッ 卜, 発泡体といった多相, 多成分の形態である。高性能材 料のためのミクロ構造の先端加コプロセス, プロセスのモ デリングのためにソフトウェア，プロセスコントロールの 装置開発，コントロール技術の開発のために様々な学問分 野からアプローチされている。当研究所は, 幾つかの技術 グループ, 協会, 共同研究プロジェクト, マルチークライ アントリサーチプロジェクト, 産業フォーラムを通じて, 産業界, 大学, 政府研究機関との密接な協力の下に活動を 行っている。
(訳)市 橋 秀 樹

\section{IMI の歴史}

IMI は 1978 年に Industrial Materials Research Institute（IMRI）として設立され，当初は仮住まいの環境か ら, 国内および海外の大学, 研究機関, 産業界との共同研 究プロジェクトと共に, 研究所独自の研究プログラムをス タートした。 1982 年の終わりには，100人近い従業員と 4 つの科学セクションを持つ研究所となり, その活動は, 成 形プロセスの開発と最適化, 新材料の開発とキャラクタリ ゼーション, 材料特性の最適化と材料, 構造物の非破壊検 查であった.さらに, これらの活動に加えて, 産業ニーズ に即した材料の技術的, 経済的な研究が行われた。翌年, 研究所はBouchervilleに移動し(建物 13,746 m³), 1989 年にその名を Industrial Materials Institute（IMI）に変更 した。

今日, IMI は 153 名の職員と 85 名を越える人々（客員

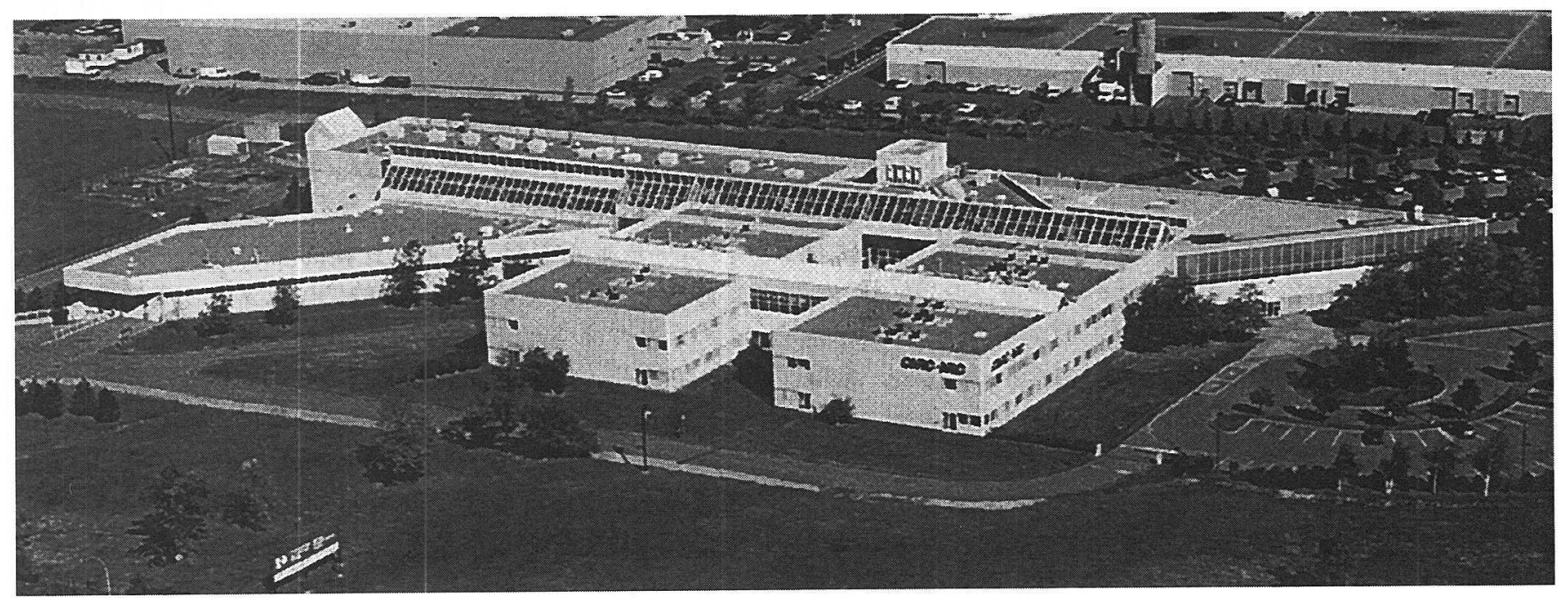

Aerial view of the NRCC Industrial Materials Institute

\footnotetext{
${ }^{* 1}$ Leszek A. Utracki

National Research Council Canada

Industrial Materials Institute

75 de Mortagne Boulevard

Boucherville, Quebec, J4B6Y4, Canada

*2 Ichihashi, Hideki

宇部興産(侏) 宇部研究所機能材第二研究部

宇部市大字小串 1978-96（广755-8633）

2000.6.13 受理
} 
教授, 客員研究員, ポストドクターフェロー, 学生等) を 抱えている. 科学技術の成長とともに, IMI の活動に対す る産業界からの参加は着実に数を増してきた。これらは, ジョイントプロジェクト, 協会への参加, IMI の特許ライ センスに基づいた製造や商品販売のための新しい企業の設 立などを含んでいる，その専門知識は，プロセスのモデリ ングと実験的研究, プロセス開発, そして光学や超音波セ ンサーを用いたプロセスコントロールシステムの開発と いった 3 つの領域にわたっている.

\section{2. 研究活動の構成}

研究所の 125 人の研究スタッフは 2 つの技術セクション に分けられ, それぞれのセクションは 4 つのグループを 持っている.

\section{(1) 材料設計と加工}

1）ポリマー複合材料

2) ポリマー材料工学

3）ネットシェイプ金属成形

4）表面技術

(2) プロセスモデリングと装置化

1) 光学センサー

2 ）プロセスの超音波測定

3）プロセスの数値モデリング

4 ）プロセスの統合モデリング

ポリマーに関係する活動はグループ(1)-1) と(1)-2)に集中

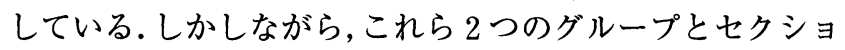
ン 2 の 4 つのグループは, 相互に深く関係しながら研究を 進めており, 具体的には, 物理的な劣化を研究するための光 学センサーの利用, 押出成形の超音波モニタリング, ブロー 成形や射出成形のプロセスのモデリング等が行われている.

\section{3. 研究室}

研究所の使命が産業の支援であったため, 開設の当初か ら, 実験室規模から小型生産規模の装置があるパイロット ラボを整えてきた。

コンパウンディング・ミキシング装置はインターナルミ キサー (Brabender, Banbury, Welex 等), Farrel Continuous Mixer (FCM), 二軸押出機 (TSE), そして IMIが 設計したExtensional Flow Mixer (EFM) を含むその他 の混合機がある. 押出し装置は, 単軸押出機（SSE，スク リュ径 12〜 $64 \mathrm{~mm}$ ), 5 台の SSE を備えたフィルムブロー イングラインと $100 \mathrm{~mm}$ のダイ, そして 3 台の TSE（ス クリュ径 $30,34,50 \mathrm{~mm}$ ）がある. 成形プロセスは, 2 台 の射出 (複合射出) 成形機 (150と 400 トン), そして 1 部品当りの樹脂量 $3 \mathrm{~kg}$ までの容量を持つ 3 台のブロー成 形ユニット (stretch, extrusion, そして co-extrusion blow molding）がある. 複合材料の研究には, オートクレーブ (チャンバー容量 $0.14 \mathrm{~m}^{3}, \mathrm{~T}=500^{\circ} \mathrm{C}, \mathrm{P}=5.5 \mathrm{MPa}$ ), 数 台のプレス（最大 $600 \mathrm{t}$ ), その他の成形機が設置されてい る.さらに, 押出された材料に配向を付加するために設計 された装置として, 温度と速度の制御が可能な圧力ロー ラーと二軸延伸ユニットがある. 発泡の研究には押出機と 数台の高圧反応オートクレーブを使用している.

当研究所は数台のキャピラリーと動的粘弾性測定器を備
えた国内最高水準の実験室を有している，特徴的なもの は，2台の異なる伸長レオメー夕（Münstedt 型と Meissner 型）を使用した伸長粘度測定である.

力学試験のための ASTM 規格の実験室, 分光器 (FTIR, ラマン, NIR-IR, UV-VIS, 複屈折分光器, XRD), 熱分析 (DSC, TGA, PVT 測定器), 顕微鏡 (光学, SEM), 溶液 分析 (GC, SEM, キャピラリー粘度計), 規格試験器 (QUV ウェザーメーター, 摩擦, 衝撃試験機, 粒子測定, Vicat 軟化点および HDT 試験器, MFI), レーザーと超音波の 試験室等の一般的な試験の実験室がある.

\section{4. 研究トピックス}

歴史的に, 当研究所はブレンド, コンポジット, 発泡材, 配向された半結晶材料等の多相, 多成分のポリマーに関す る研究に注力してきた.これらの分野での研究のトピック

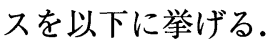

(1) ポリマーブレンド

1) TSE内のコンパウンディング中のモルホロジーの評価

2）モルホロジーと流動挙動の関係

3) エンジニアリングブレンドの反応相溶化

4) Extensional Flow Mixer (EFM) による SSE のブ レンドコンパウンディング能力の向上（例えば，熱 可塑性プラスチックス中へのエラストマーの分散へ の EFMの利用)

(2) ポリマーコンポジット

1) クレーのインターカレーションによるポリマーナノ コンポジット

2) PVT と力学的挙動における固体の添加の効果

3 ）熱硬化コンポジットの性能における加工条件の効果

4 ）連続繊維熱可塑コンポジット - 加工, 成形, アセン ブリング，特性，長期挙動

5 ）多相ポリマー系の破壊力学

(3) ポリマー発泡凮

1）環境にやさしい発泡剂を用いた低比重ポリマー発泡材

2）圧縮ガスまたは揮発性液体を用いた押出発泡成形中 の粘度変化予測への hole-lattice 理論の利用

3 ）マイクロセルラー発泡材の作成

4 ）発泡性と発泡品質におけるひずみ硬化の影響

(4) 配向ポリマー

1 ）配向の複屈折測定

2 ）配向材料の耐衝撃性

3 ) 半結晶性材料の固相成形 (PET,PP,s - PS)

4 ）フィルムの配向, 応力, 収縮

さらに, 8つの Technology and Special Interest Groups で次のような研究プロジェクトが実施されている.

\section{Technology and Special Interest Groups}

1989 年以来, IMI は企業に対して, 市場ニーズに合致 した技術を徐々に習得できる，独自の技術移管方法として Technology and Special Interest Groups を提供している. ここでは, メンバー（企業, 大学, 研究所もしくは工業団 体) と IMI が共通の感心事項を満たすよう最適な研究開 発プログラムを決定し, 実行している. 競争に要するコス トを分担し，共同で研究開発を行い，さらにメンバーには 
次のような利点がある.

1 ）最新技術と最適手法の工業的適用

2) メンバー間の有益な相互関係

3 ）技術的補助と従業員のトレーニング

4 ）最先端の装置と世界中の技術情報の利用

現在メンバーの数は 100 近くまで増えており, 採用され たプログラムがパートナーのニーズに対して柔軟で, 能率 良く, 適切なものであることを示している.これらは, 個々 の企業との共同研究プログラムに発展する場合も多い.

現在, Technology and Special Interest Groups には次 のようなグループがある.

A. Special Interest Group in Injection Molding (SIGIM)

B. Special Interest Group in Die Casting(SIGCAST)

C. Special Interest Group in Blow Molding (SIGBLOW)

D. Surface Engineering Technology Group-Aerospace (SURF TEC Aerospace)

E. Surface Engineering Technology Group-Resources (SURFTEC Resources)

F. Technology Group on Polymer Foams (FOAMTECH)

G. Special Interest Group in Thermoforming (SIGFORM)

H. Special Interest Group in Continuous Fiber Polymer Composites (SIGCOMP)

メンバーの企業は，例えば交通，航空宇宙，製鉄，プラ スチックス, 食品包装，情報産業等のように様々な産業が カナダ，アメリカ，ヨーロッパ，日本から参加している.

これら 8 つグループで実行されている研究開発プログ ラムの例を以下に挙げる.

\begin{tabular}{|c|c|}
\hline グループ & 研 究 活 動 \\
\hline $\mathbf{A}$ & 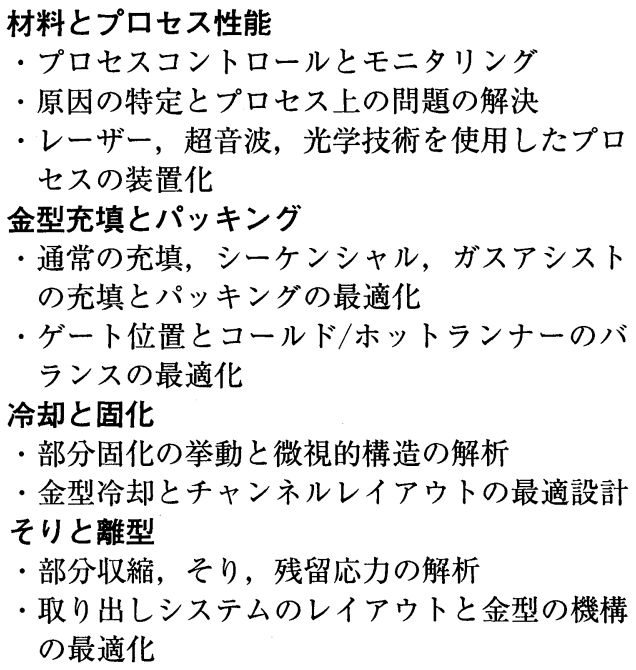 \\
\hline B & $\begin{array}{l}\text { プロセスコントロールとモニタリング } \\
\text { ダイ/金型充填と加圧 } \\
\text { 冷却と固化 } \\
\text { そりと離型 } \\
\text { 材料とプロセス性能 }\end{array}$ \\
\hline
\end{tabular}

\begin{tabular}{|c|c|}
\hline グループ & 研 究 活 動 \\
\hline C &  \\
\hline D & $\begin{array}{l}\text { 次を目的とした被覆の微視構造の最適化のため } \\
\text { の材料開発 } \\
\text { ·耐摩耗性 } \\
\text { ·室温, 高温での耐侵食性 } \\
\text { ·電極の防食 } \\
\text { ・ハードクロムの代替 } \\
\text { ·固体潤滑コーティング } \\
\text { 機能性コーティング } \\
\text { •電極材料 }\end{array}$ \\
\hline $\mathbf{E}$ & $\begin{array}{l}\text { 前処理 } \\
\text { 修飾材料 } \\
\text { プラズマ修飾 } \\
\text { 高速修飾 } \\
\text { アーク放電修飾 } \\
\text { コントロールと検查 }\end{array}$ \\
\hline $\mathbf{F}$ & 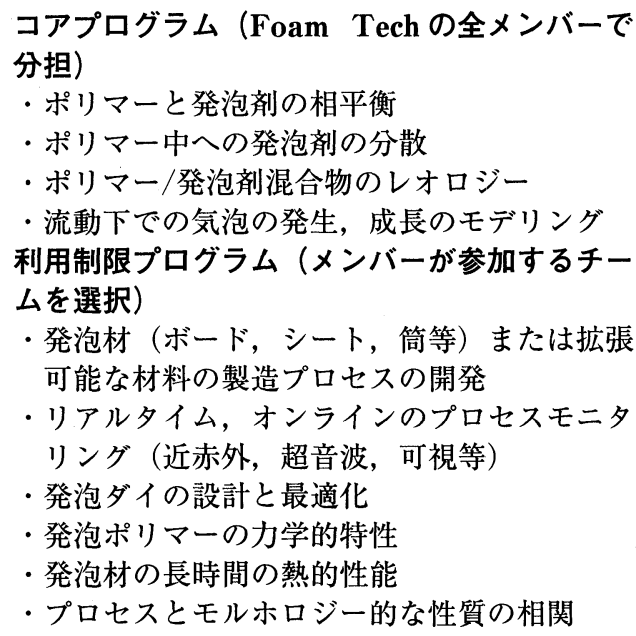 \\
\hline G & $\begin{array}{l}\text { 材料とプロセス性能 } \\
\text { •特性のキャラクタリゼーションと制御条件の } \\
\text { 範囲 } \\
\text { ·物理的特性, バリア特性, 機械的特性の最適化 } \\
\text { プロセスコントロールとモニタリング } \\
\text { ·原因の特定とプロセス上の問題の解決 } \\
\text { ・レーザー, 超音波, 光学技術を利用したプロ } \\
\text { セスの装置化 }\end{array}$ \\
\hline
\end{tabular}




\begin{tabular}{|c|c|}
\hline グループ & 研 究 活 動 \\
\hline G & 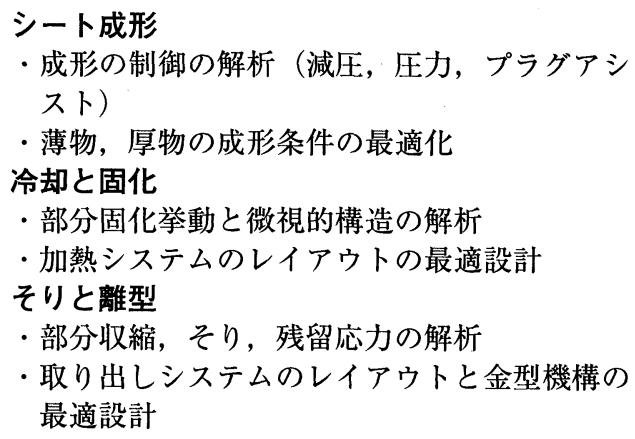 \\
\hline $\mathbf{H}$ & 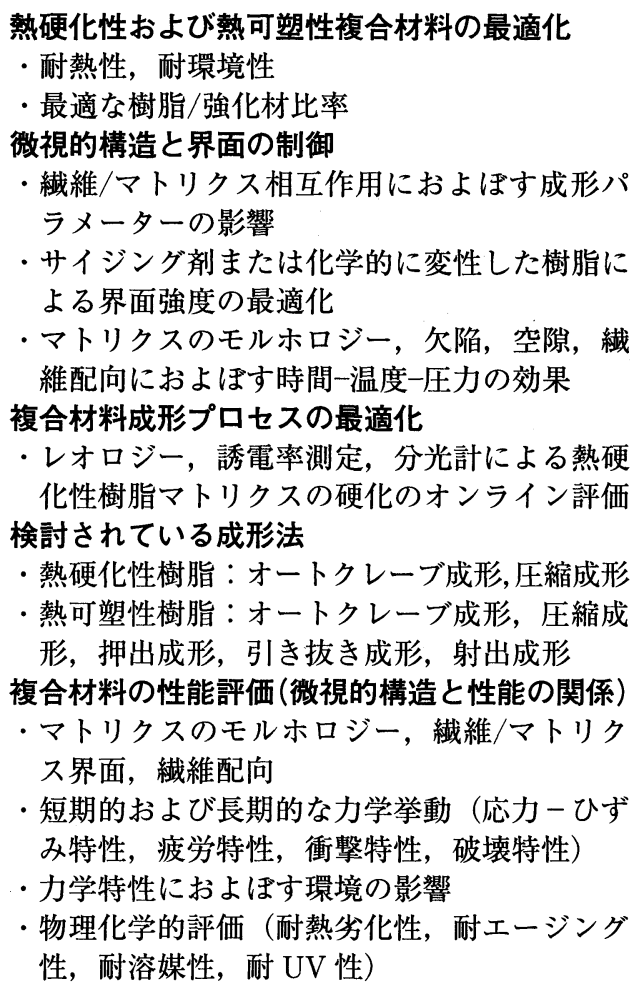 \\
\hline $\mathbf{H}$ & 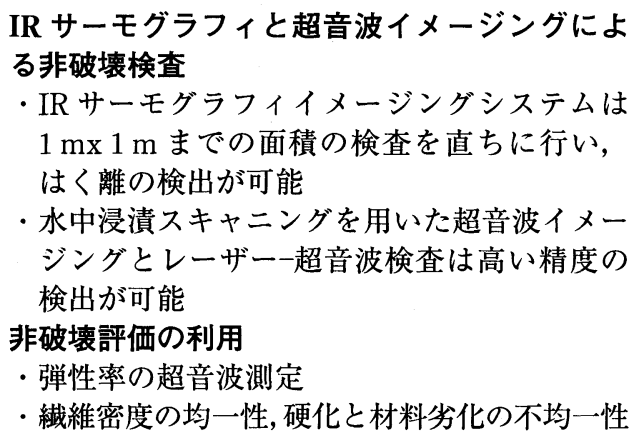 \\
\hline
\end{tabular}

\section{6. 周 辺}

IMI は Montreal から北東に $20 \mathrm{~km}$ の Boucherville に有 り, セントローレンス川の南岸に位置する. Boucherville は 1667 年の創立者 Pierre Boucherにちなんで名づけられ た（彼の邸宅はいまだに建っている）。第二次世界大戦以 後, Boucherville は Montrealの郊外住宅地として開発さ れた. 1996 年の人口は 34,989 人である.

Montreal は 17 世紀の終わりまでは，人口わずかに 1000 人の毛皮貿易の町であった. カナダ連邦設立後（1867 年） 急速に発展し, 今日, Montreal とその衛星都市の人口は 300 万人近い. Montreal は工業, 流通, 商業の主要な中 心都市である. その原点の通り, いまだに毛皮貿易の国際 的中心でありながら，同時にハイテク工業の中心にもなり つつある.また，4つの有名大学, (Universite de Montreal, Universite du Quebec a Montreal,McGill University と Concordia University) そしていくつかの大学レベルの機 関が立地する。

Montreal は強いフランス的な趣を持った, 活発で多文 化的な都市である. 祭り, ファッション, 美食等, 多彩な すばらしい文化を持った，旅行書における「是非とも訪れ るべき」場所である. Montreal は美しく, 多彩で, けっ して飽きることの無い, 訪れてすばらしく，住んでなお良 い都市である。 